University of Nebraska - Lincoln

DigitalCommons@University of Nebraska - Lincoln

Faculty Papers and Publications in Animal

Science

Animal Science Department

1980

\title{
Effect of Dietary Lactose on Gain, Feed Conversion, Blood, Bone and Intestinal Parameters in Postweaning Rats and Swine
}

\author{
R. L. Moser \\ University of Nebraska-Lincoln \\ E. R. Peo, Jr. \\ University of Nebraska-Lincoln \\ T. D. Crenshaw \\ University of Nebraska-Lincoln \\ P. J. Cunningham \\ University of Nebraska-Lincoln
}

Follow this and additional works at: https://digitalcommons.unl.edu/animalscifacpub

Part of the Animal Sciences Commons

Moser, R. L.; Peo, Jr., E. R.; Crenshaw, T. D.; and Cunningham, P. J., "Effect of Dietary Lactose on Gain, Feed Conversion, Blood, Bone and Intestinal Parameters in Postweaning Rats and Swine" (1980). Faculty Papers and Publications in Animal Science. 647.

https://digitalcommons.unl.edu/animalscifacpub/647

This Article is brought to you for free and open access by the Animal Science Department at DigitalCommons@University of Nebraska - Lincoln. It has been accepted for inclusion in Faculty Papers and Publications in Animal Science by an authorized administrator of DigitalCommons@University of Nebraska - Lincoln. 


\title{
EFFECT OF DIETARY LACTOSE ON GAIN, FEED CONVERSION, BLOOD, BONE AND INTESTINAL PARAMETERS IN POSTWEANING RATS AND SWINE ${ }^{1,2}$
}

\author{
R. L. Moser, E. R. Peo, Jr., T.D. Crenshaw \\ and P. J. Cunningham ${ }^{3}$
}

University of Nebraska, Lincoln 68583

\begin{abstract}
Summary
Two trials were conducted to determine the effect of lactose on performance, bone integrity and certain blood constituents in postweaning rats and swine. The effect of lactose on calcium and phosphoriss and percentage ash content of the small intestine was also determined. In both trials, average daily gains were not influenced by the feeding of diets containing $30 \%$ lactose. Feed conversion was depressed in both rats and pigs when $30 \%$ lactose was fed. Transitory diarrhea was observed in rats fed $30 \%$ lactose, but not in swine. In the rat trial, no significant differences due to treatment were observed for serum $\mathrm{Ca}$ or $\mathrm{P}$, but a linear increase $(\mathrm{P}<.01)$ in alkaline phosphatase was observed as lactose increased in the diet. Analysis of blood constituents from multiple bleedings during the pig trial showed that in the first 2 weeks, alkaline phosphatase was increased $(P<.01)$ in pigs fed lactose and slightly decreased in those not fed lactose. Lactose affected the change in serum $\mathrm{Ca}$ from 0 to 10 weeks $(\mathrm{P}<.05)$ as indicated by a marked reduction in serum $\mathrm{Ca}$ of pigs not fed lactose and a slight increase for those fed lactose. Serum calcium decreased in the absence of lactose but increased in the presence of lactose $(\mathrm{P}<.05)$ in pigs fed $.4 \%$ $\mathrm{Ca}$ diets. In both trials, breaking strength parameters (peak force and stress) were not affected by dietary lactose. Bones from pigs fed no lactose had a higher stress to strain ratio $(\mathrm{P}<.05)$ than those from pigs fed lactose. In the
\end{abstract}

\footnotetext{
${ }^{1}$ Published as Paper No. 5815, Journal Ser., Nebraska Agr. Exp. Sta.

${ }^{2}$ Dept. of Anim. Sci. Acknowledgment is made to John Welch and Barbara Petersen for their laboratory assistance and to Dawes Laboratories, Chicago, IL, for product support of the research.

${ }^{3}$ Current address: Bonneville, IA.
}

rat trial, stress to strain ratio was variable across all treatments. Percentage of bone ash increased $(\mathrm{P}<.01)$ as lactose increased in the diet. Dietary treatments did not affect the mineral content of specific gut segments.

(Key Words: Lactose, Ca:P Ratio, Serum Calcium, Alkaline Phosphatase, Bone Strength, Swine, Rat.)

\section{Introduction}

The importance of lactose as the primary carbohydrate in the diet of suckling animals has been recognized for many years. Lactose functions primarily as an energy source but is considered to perform other functions, such as improving protein, calcium and magnesium digestibility (Sewell and West, 1965; Entringer et al., 1975).

The nutritional and physiological roles of lactose seem to diminish with time because (1) the specific activity of lactase in the digestive tract decreases with age (Simoons, 1969; Ekstrom et al., 1975a), and (2) the animal no longer receives lactose from milk because milk is replaced with diets made up largely of plant feedstuffs. Also, moderate to high levels of dietary lactose fed to postweaning animals have caused digestive upsets, specifically diarrhea (Becker et al., 1957).

Lactose has been found to enhance the absorption of calcium ( $\mathrm{Ca}$ ) from the digestive tract in a variety of species, including rats (Lengemann et al., 1959), chicks (Kline et al., 1932), dairy calves (Robinson et al., 1929) and humans (Kobayashi et al., 1975). Limited research in this area has been conducted with swine.

Armbrecht and Wasserman (1976) recently showed that lactose enhances the uptake of $\mathrm{Ca}$ from the ileum of the small intestine of rats. Since $\mathrm{Ca}$ and phosphorus (P) play vital roles in mineral nutrition and since lactose seems to 
be involved in the absorption of $\mathrm{Ca}$, the objectives of the research reported herein were (1) to determine the effect of lactose on performance, bone integrity and certain blood constituents in postweaning rats and swine and (2) to determine the effect of lactose on mineral content of certain gut segments of the small intestine of swine.

\section{Experimental Procedure}

Animals

Rat Trial. Sixty Holtzman rats $(54 \mathrm{~g})$ were allotted to six treatment groups (10 rats per treatment) in a randomized complete block design (blocked by initial weight). Sex distribution was the same for each treatment. The rats were weaned at 3 weeks of age and fed a standard laboratory diet until allotted to the treatments at 4 weeks of age. Rats were individually caged, with feed and water offered $a d$ libitum. All rats were weighed and feed intakes were recorded weekly. The experiment was terminated after 28 days.

Pig Trial. Ninety-six crossbred (Large White $\times$ Landrace $\times$ Hampshire $\times$ Duroc $\times$ Yorkshire) pigs $(31 \mathrm{~kg})$ were allotted to eight treatment groups in a randomized complete block design (blocked by weight). Eight pigs (two barrows and six gilts) were placed in each pen.
Treatments 2, 4, 6 and 8 were replicated to provide feed intake and feed efficiency data. Feed and water were offered ad libitum. Pigs were weighed biweekly and feed intakes were recorded over a 70 -day feeding period.

\section{Diets}

Rat Trial. Experimental diets consisted of a corn-soybean meal base with various levels of cornstarch and lactose (see table 1 for composition). Diets 1,2 and 3 contained 0,15 and $30 \%$ cornstarch, respectively; diets 4,5 and 6 were prepared with 10,20 and $30 \%$ lactose substituted for cornstarch. The total amount of purified carbohydrate in diets $3,4,5$ and 6 was $30 \%$. All diets were formulated to contain $16 \%$ crude protein, $.6 \% \mathrm{Ca}$ and $.6 \% \mathrm{P}$, and analyses revealed the actual percentages to be 17.0 , .59 and .62 , respectively.

Pig Trial. Experimental diets (table 2) consisted of a corn-soybean meal base with 0 or $30 \%$ lactose, with .4 or $.6 \% \mathrm{Ca}$ and .4 or $.6 \% \mathrm{P}$. Diets containing no lactose included $30 \%$ cornstarch so that the total addition of purified carbohydrate sources remained the same in all diets. Diets were calculated to contain $14 \%$ crude protein.

Blood. At the end of the rat trial, each rat was anesthctized with ether, and a blood

TABLE 1. COMPOSITION OF DIETS. RAT TRIAL

\begin{tabular}{|c|c|c|c|c|c|c|c|}
\hline \multirow[b]{2}{*}{ Ingredient, \% } & \multirow{2}{*}{$\begin{array}{l}\text { Internat'l } \\
\text { Ref. No. }\end{array}$} & \multicolumn{6}{|c|}{ Diet } \\
\hline & & 1 & 2 & 3 & 4 & 5 & 6 \\
\hline Ground yellow corn & $4-02-992$ & 76.00 & 57.15 & 38.21 & 38.21 & 38.21 & 38.21 \\
\hline Soybean meal (44\%) & $5-04-604$ & 17.10 & 20.90 & 24.80 & 24.80 & 24.80 & 24.80 \\
\hline Cornstarch ${ }^{b}$ & 4-02-889 & $\ldots$ & 15.00 & 30.00 & 20.00 & 10.00 & $\ldots$ \\
\hline Lactosec & $4-07-881$ & $\ldots$ & $\cdots$ & $\ldots$ & 10.00 & 20.00 & 30.00 \\
\hline Dicalcium phosphate & $6-01-080$ & 1.30 & 1.46 & 1.62 & 1.62 & 1.62 & 1.62 \\
\hline Limestone & $6-02-632$ & .50 & .39 & .27 & .27 & .27 & .27 \\
\hline Dried brewer's yeast & $7-05-528$ & 1.00 & 1.00 & 1.00 & 1.00 & 1.00 & 1.00 \\
\hline Dried fish solubles & $5-01-971$ & 2.50 & 2.50 & 2.50 & 2.50 & 2.50 & 2.50 \\
\hline Salt & $6-04-151$ & .50 & .50 & .50 & .50 & .50 & .50 \\
\hline Trace minerals $d$ & & .10 & .10 & .10 & .10 & .10 & .10 \\
\hline \multirow[t]{2}{*}{ Vitamin premix } & & 1.00 & 1.00 & 1.00 & 1.00 & 1.00 & 1.00 \\
\hline & & 100.00 & 100.00 & 100.00 & 100.00 & 100.00 & 100.00 \\
\hline
\end{tabular}

${ }^{\mathrm{a}}$ Calculated analysis: $16 \%$ crude protein $.6 \% \mathrm{Ca} .6 \% \mathrm{P}$.

${ }^{b}$ Commerical cornstarch.

$\mathbf{c}_{\alpha \text {-lactose monohydrate. }}$

${ }^{d}$ Contributed the following in milligrams per kilogram of diet: $\mathrm{Zn} 200 ; \mathrm{Fe}, 100 ; \mathrm{Mn}, 55 ; \mathrm{Cu}, 10 ; \mathrm{Co}, 1 ; \mathrm{I}, 1.5$

${ }^{e}$ Contributed the following per kilogram of diet: vitamin A, 3,300 USP units; vitamin $D_{3}, 440$ ICU; vitamin E, $22 \mathrm{IU}$; riboflavin, $2.2 \mathrm{mg}$; pantothenic acid, $13.2 \mathrm{mg}$; niacin, $17.6 \mathrm{mg}$; choline chloride, $110 \mathrm{mg}$; vitamin $B_{12}$, $2.2 \mathrm{mcg}$; ethoxyquin, $4.4 \mathrm{mcg}$; menadione sodium bisulfate, $2.2 \mathrm{mg}$; in a ground corn carrier. 


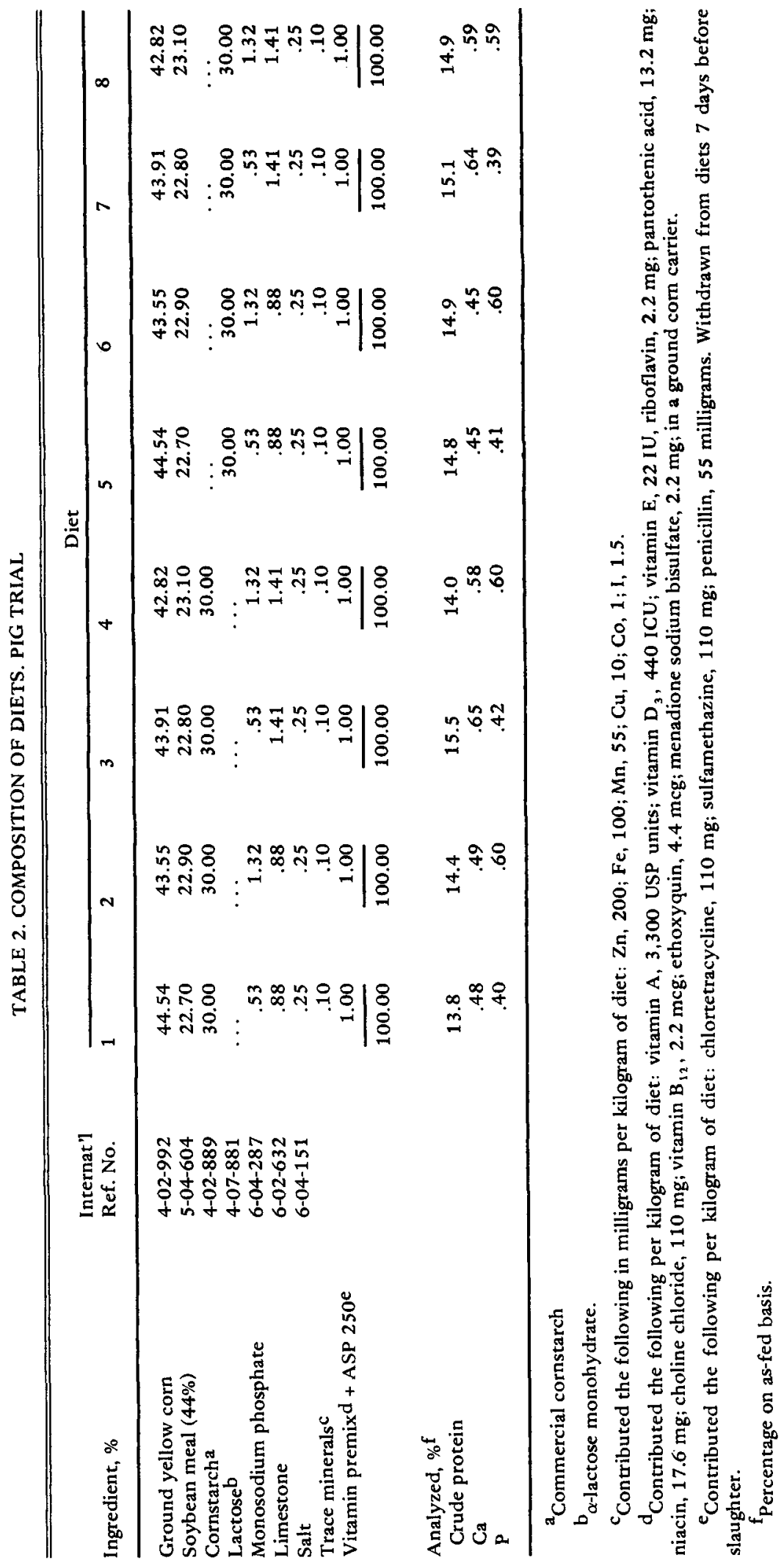


sample was taken via heart puncture. In the pig trial, blood samples were taken via brachial puncture at 0,2 and 10 weeks. Serum $\mathrm{Ca}$ concentration was determined by atomic absorption spectrophotometry ${ }^{4}$. Serum concentration was determined on the protein-free filtrate prepared by trichloroacetic acid precipitation. $\mathbf{P}$ analysis was carried out colorimetrically by the method of Goldenberg and Fernandez (1966). Serum alkaline phosphatase activity was determined according to a colorimetric method of the Sigma Chemical Co. (1974), with paranitrophenyl phosphate used as the substrate. Sigma units per milliliter were converted to IU/liter by multiplying by a factor of 16.7 .

Bones. The femur and third and fourth metatarsals from the right side of each pig and both femurs of each rat were removed at the end of the respective trials. Bones were autoclaved at $110 \mathrm{C}$ for $10 \mathrm{~min}$ and cleaned of all adhering tissue. Rat fermurs were ether extracted for $24 \mathrm{hr}$ with a side-arm extraction apparatus. Outside diameter of the bones was calculated as the average of two measurements $90^{\circ}$ to each other at the center of each bone. Cross-sectional area of the bone was estimated with the formula shown in table 3 . Bone breaking strength was determined with an Instron testing instrument ${ }^{5}$. Bones were placed on two supports and force was applied at the center of the bone. The distance between the two supports for pig femurs and metatarsals was 7.8 and $4.2 \mathrm{~cm}$, respectively; rat femurs were placed on two supports $11 \mathrm{~mm}$ apart. The parameters utilized for estimation of bone strength are listed in table 3. Broken rat femurs were dried overnight at $100 \mathrm{C}$, weighed and ashed in a muffle furnace at $600 \mathrm{C}$ for $4 \mathrm{hr}$ for determination of percentage ash.

Tissues. At slaughter, the digestive tracts of the five heaviest pigs (one barrow and four gilts) from each treatment were selected for mineral analysis. One segment was removed from each of three gut sections: duodenum, jejunum and ileum. To obtain the segments, two cross-sectional cuts were made $3 \mathrm{~cm}$ apart. Segments were then severed longitudinally and rinsed with distilled water. Segments from the duodenum were removed $10 \mathrm{~cm}$ distal to the

\footnotetext{
${ }^{4}$ Perkin-Elmer Model 303 Atomic Absorption Spectrophotometry, Perkin-Elmer Co., Norwalk, CT

${ }^{5}$ Model TM 1123, Instron Corp., Canton, MA.
}

TABLE 3. FORMULAS FOR ESTIMATING CER-

TAIN PHYSICAL CHARACTERISTICS AND BREAKING STRENGTH OF BONES. RAT AND PIG TRIALS

Item

$\begin{array}{ll}\text { Cross-sectional area, } \mathrm{cm}^{2} & =\left(\frac{\text { diameter }}{2}\right)^{2} \cdot \pi \\ \text { Peak force, } \mathrm{kg} & \\ \text { Stress, } \mathrm{kg} / \mathrm{cm}^{2} & =\frac{\text { Peak force }}{\text { cross-sectional area }} \\ \text { Stress: } \mathrm{strain}, \mathrm{kg} / \mathrm{cm}^{2} / \mathrm{mm}^{\mathrm{a}} & =\frac{\text { stress }}{\text { deformation, } \mathrm{mm}}\end{array}$

${ }^{\mathbf{a}}$ Bone deformation due to applied force.

attachment of the common bile duct to the duodenum. Jejunal and ileal segments were removed $3 \mathrm{~m}$ and $10 \mathrm{~cm}$ proximal to the cecum, respectively. Gut segments were then frozen and stored for subsequent mineral analyses. Gut segments were washed of all adhering digesta, blotted dry, weighed and ashed in a muffle furnace at $600 \mathrm{C}$ for 4 hours. $\mathrm{Ca}$ and $\mathrm{P}$ concentrations of the segments were analyzed by methods cited previously.

Data on performance and blood constituents in the rat trial were analyzed by least-squares analysis as outlined by Harvey (1960). All other data were analyzed by analysis of variance methods described by Barr and Goodnight (1972) and Steel and Torrie (1960).

\section{Results and Discussion}

Rat Trial

Gain, feed consumption and feed efficiency of the rats are shown in table 4. No significant differences in average daily gain or average daily feed intake were observed among treatments. There was a trend for poorer growth rate as lactose increased in the diet (treatments 4,5 and 6). Rats fed diet 2 (containing $15 \%$ cornstarch) had the lowest average gain and feed intake, largely because of an extremely poor performance by one rat. Feed to gain ratio increased $(\mathrm{P}<.01)$ as dietary lactose increased in the diets. Feed efficiency was similar for rats fed up to $20 \%$ dietary lactose and rats fed the corn-soybean meal control; rats fed $30 \%$ lactose had the poorest feed efficiency.

During the first week, growth rate was $29 \%$ slower in rats fed $30 \%$ lactose (treatment 6 ) 


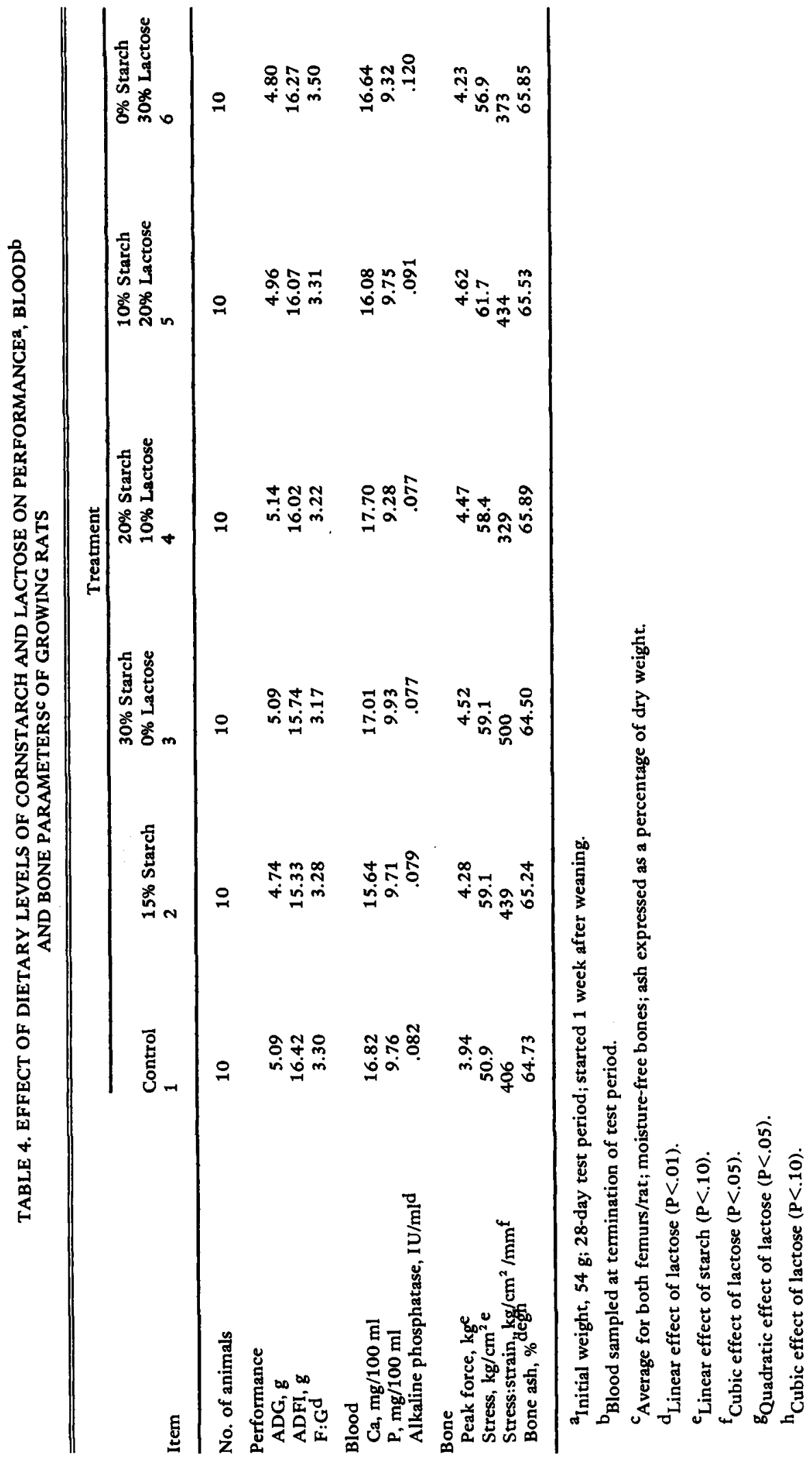


than in rats fed the control diet. Rats assigned to treatments $2,3,4$ and 5 showed a response similar to that of those fed the control diet. All rats fed $30 \%$ lactose exhibited marked diarrhea, enlarged abdomens and rough hair coats, while rats fed other diets containing lactose showed none of these symptoms. After 1 week, rats fed $30 \%$ lactose performed as well as rats fed other diets; as a result, there were no significant differences in overall gain between treatments. Also, no signs of diarrhea or other symptoms of lactose feeding were observed throughout the remainder of the trial.

The effects of dietary levels of cornstarch and lactose on serum $\mathrm{Ca}, \mathrm{P}$ and alkaline phosphatase are summarized in table 4 . No significant differences were observed among treatment means for serum $\mathrm{Ca}$ and $\mathrm{P}$, but serum alkaline phosphatase increased linearly $(P<.01)$ as lactose increased in the diets, with the greatest increase (32\%) observed between treatments 5 and 6.

The effects of levels of lactose and cornstarch on bone strength parameters and percentage of ash are summarized in table 4. Peak force and stress increased linearly $(P<.10)$ with increasing levels of cornstarch. No significant differences in either peak force or stress were observed among lactose treatments. Stress to strain ratios of femurs varied from treatment to treatment, with higher $(\mathrm{P}<.05)$ ratios obtained for bones from rats fed treatments 3 and 5 than for bones from rats fed treatments 4 and 6 . Percentage of bone ash decreased $(\mathrm{P}<.10)$ as dietary cornstarch increased. In contrast, percentage ash increased as lactose increased (linear effect $\mathrm{P}<.01$; quadratic $\mathrm{P}<.05$ ). Overall, the percentage ash of femurs from rats fed lactose and of those from rats not fed lactose were 65.8 and $64.8 \%$, respectively.

\section{Pig Trial}

The effects of lactose level on gain, feed intake and feed conversion are presented in table 5. Ca and P level had no effect on performance; therefore only comparisons of pigs fed lactose versus no lactose are shown. Average daily gain was not affected by level of lactose. Pigs fed lactose consumed more $(\mathrm{P}<.01)$ feed and had poorer $(\mathrm{P}<.01)$ feed conversion than pigs fed no lactose.

The effect of lactose and $\mathrm{Ca}$ and $\mathrm{P}$ levels on changes in serum $\mathrm{Ca}$ concentrations at three bleeding periods are summarized in table 6 . No
TABLE 5. EFFECT OF LEVEL OF LACTOSE ON GAIN, FEED INTAKE AND FEED CONVERSION OF GROWING-FINISHING SWINE ${ }^{a}$

\begin{tabular}{lrr}
\hline & \multicolumn{2}{c}{ Lactose, \% } \\
\cline { 2 - 3 } Item & $0^{\mathrm{b}}$ & 30 \\
\hline Avg daily gain, kg & .78 & .79 \\
Avg daily feed intake, $\mathrm{kgc}^{\mathrm{c}}$ & 2.11 & 2.32 \\
Feed to gain ratioc & 2.66 & 2.94 \\
\hline
\end{tabular}

anitial weight, $31 \mathrm{~kg}$; 70-day test.

${ }^{b}$ Control diets contained $30 \%$ cornstarch.

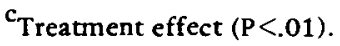

significant differences in change of serum $\mathrm{Ca}$ were observed among treatments during the first 2-week period. Dietary $P$ level affected $(\mathrm{P}<.05)$ changes in serum $\mathrm{Ca}$ during the 2- to 10-week period, with serum levels decreasing in pigs fed .4\% $\mathrm{P}$ but increasing in pigs fed .6\% $\mathrm{P}$. The change in serum $\mathrm{Ca}$ concentration for the total test period ( 0 to 10 weeks) was affected $(\mathrm{P}<.05)$ by dietary lactose level. Serum $\mathrm{Ca}$ of pigs fed no lactose was drastically reduced while that of pigs fed lactose increased slightly. Also there was a significant $(\mathrm{P}<.05)$ lactose level $\times \mathrm{Ca}$ level interaction on serum $\mathrm{Ca}$ change for the total test period, with serum $\mathrm{Ca}$ decreasing in the absence of lactose but increasing in the presence of lactose in pigs fed $.4 \%$ dietary $\mathrm{Ca}$. Pigs fed $.6 \% \mathrm{Ca}$ responded in the same manner (with respect to serum $\mathrm{Ca}$ ) when fed either level of lactose.

The effects of dietary treatment on changes in serum $P$ concentration are shown in table 7. Serum $P$ decreased with time across all treatments. During the 2- to 10 -week bleeding period, the decrease $(-1.31)$ was more dramatic $(\mathrm{P}<.05)$ in pigs fed lactose than in pigs fed no lactose $(-.62)$.

The effects of lactose and $\mathrm{Ca}$ and $\mathbf{P}$ levels on change in serum alkaline phosphatase activity at three bleeding periods are shown in table 8 . Lactose affected the change in alkaline phosphatase activity from 0 to 2 weeks $(P<.01)$ as revealed by a sharp increase $(+.022)$ in activity in pigs fed lactose compared to a slight decline $(-.007)$ in pigs fed no lactose. During the second bleeding period (2 to 10 weeks), alkaline phosphatase activity decreased in all pigs. However, the decrease $(-.049)$ was greater $(\mathrm{P}<.01)$ in pigs fed lactose than in pigs fed no 
TABLE 6. EFFECT OF LEVEL OF LACTOSE AND CA AND P LEVELS AND RATIOS ON CHANGES IN SERUM CA OF GROWING-FINISHING SWINEa

\begin{tabular}{|c|c|c|c|c|}
\hline \multirow{2}{*}{$\begin{array}{l}\text { Dietary level of } \\
\text { lactose, } \%\end{array}$} & \multirow{2}{*}{$\begin{array}{l}\text { Dietary level of } \\
\text { Ca and } P, \%\end{array}$} & \multicolumn{3}{|c|}{ Serum Ca change (mg/dl) by period (weeks) } \\
\hline & & 0 to 2 & 2 to $10^{b}$ & 0 to $10^{\mathrm{cd}}$ \\
\hline 0 & $\begin{array}{l}.4, .4 \\
.4, .6 \\
.6, .4 \\
.6, .6\end{array}$ & $\begin{array}{r}-1.03 \\
-1.11 \\
+.46 \\
-1.14\end{array}$ & $\begin{array}{r}-.10 \\
+.16 \\
-.51 \\
+.72\end{array}$ & $\begin{array}{r}-1.13 \\
-.95 \\
-.05 \\
-.42\end{array}$ \\
\hline 30 & $\begin{array}{l}.4, .4 \\
.4, .6 \\
.6, .4 \\
.6, .6\end{array}$ & $\begin{array}{r}+1.04 \\
-.87 \\
+.30 \\
-.48\end{array}$ & $\begin{array}{r}-.37 \\
+.99 \\
-.52 \\
+.29\end{array}$ & $\begin{array}{r}+.67 \\
+.13 \\
-.21 \\
-.19\end{array}$ \\
\hline
\end{tabular}

${ }^{a}(-)$ denotes decrease $(+)$ denotes increase.

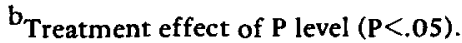

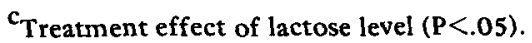

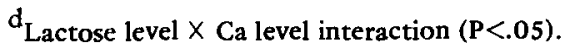

lactose $(-.026)$. Change of alkaline phosphatase activity for the total test period ( 0 to 10 weeks) was not affected by lactose level.

Dietary $\mathrm{Ca}$ levels affected alkaline phosphatase activity during the 0 - to 2-week period; activity in pigs fed either of the Ca levels was increased, but pigs fed $.4 \% \mathrm{Ca}$ showed a greater $(\mathrm{P}<.05)$ increase in activity than those fed .6\% Ca. Dietary $P$ level also affected $(P<.01)$ alkaline phosphatase activity during the 0 - to 2-week period; activity rose $(+.15)$ in pigs fed $.6 \% \mathrm{P}$ but did not change in pigs fed $.4 \% \mathrm{P}$. Dietary $\mathrm{Ca}$ and $\mathrm{P}$ levels had no effect on the overall change in alkaline phosphatase activity from 0 to 10 weeks.

The effects of lactose and $\mathrm{Ca}$ and $\mathrm{P}$ levels on peak force, stress and stress to strain ratios of bones are summarized in table 9 . No significant treatment $x$ bone interactions were observed for any of the parameters determined. Therefore, femurs, and third and fourth metatarsals were pooled across all treatments for comparisons. No significant differences were observed across all treatments for peak force or stress, but bones from pigs fed $.6 \% \mathrm{Ca}$ had a greater peak force and stress than those from pigs fed $.4 \% \mathrm{Ca}$. Pigs fed no lactose had higher $(\mathrm{P}<.05)$ stress to strain ratios than pigs fed

TABLE 7. EFFECT OF LEVEL OF LACTOSE AND CA AND P LEVELS AND RATIOS ON CHANGES IN SERUM P OF GROWING-FINISHING SWINEQ

\begin{tabular}{|c|c|c|c|c|}
\hline \multirow{2}{*}{$\begin{array}{l}\text { Dietary level of } \\
\text { lactose, } \%\end{array}$} & \multirow{2}{*}{$\begin{array}{l}\text { Dietary level of } \\
\mathrm{Ca} \text { and } \mathrm{P}, \%\end{array}$} & \multicolumn{3}{|c|}{ Serum P change ( $\mathrm{mg} / \mathrm{dl}$ ) by period (weeks) } \\
\hline & & 0 to 2 & 2 to $10^{b}$ & 0 to 10 \\
\hline $\mathbf{0}$ & $\begin{array}{l}.4, .4 \\
.4, .6 \\
.6, .4 \\
.6, .6\end{array}$ & $\begin{array}{r}-1.98 \\
-1.07 \\
-.73 \\
-.94\end{array}$ & $\begin{array}{r}-.36 \\
-.77 \\
-.49 \\
-.66\end{array}$ & $\begin{array}{r}-2.34 \\
-1.85 \\
-1.21 \\
-1.60\end{array}$ \\
\hline 30 & $\begin{array}{l}.4, .4 \\
.4, .6 \\
.6, .4 \\
.6, .6\end{array}$ & $\begin{array}{r}-.58 \\
-\quad .06 \\
-\quad .94 \\
-\quad .30\end{array}$ & $\begin{array}{r}-.52 \\
-1.78 \\
-.61 \\
-1.51\end{array}$ & $\begin{array}{l}-1.10 \\
-1.84 \\
-1.55 \\
-1.80\end{array}$ \\
\hline
\end{tabular}

${ }^{a}(-)$ denotes decrease $(+)$ denotes increase.

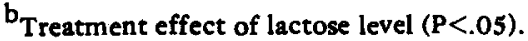


TABLE 8. EFFECT OF LEVEL OF LACTOSE AND CA AND P LEVELS AND RATIOS ON CHANGES IN SERUM ALKALINE PHOSPHATASE OF GROWING-FINISHING SWINE

\begin{tabular}{|c|c|c|c|c|}
\hline \multirow{2}{*}{$\begin{array}{l}\text { Dietary level of } \\
\text { lactose, } \%\end{array}$} & \multirow{2}{*}{$\begin{array}{l}\text { Dietary level of } \\
C_{2} \text { and } P, \%\end{array}$} & \multicolumn{3}{|c|}{$\begin{array}{c}\text { Serum alkaline phosphatase } \\
\text { Change (IU/ml) by period (weeks) }\end{array}$} \\
\hline & & 0 to $2^{\text {bcdef }}$ & 2 to $10 \mathrm{bcgh}$ & 0 to $10^{i}$ \\
\hline \multirow[t]{4}{*}{0} & $.4, .4$ & -.021 & -.021 & -.042 \\
\hline & $.4, .6$ & +.002 & -.032 & -.031 \\
\hline & $.6, .4$ & -.004 & -.026 & -.030 \\
\hline & $.6, .6$ & -.011 & -.023 & -.034 \\
\hline \multirow[t]{4}{*}{30} & $.4, .4$ & +.005 & -.048 & -.043 \\
\hline & $.4, .6$ & +.028 & -.049 & -.021 \\
\hline & $.6, .4$ & +.018 & -.055 & -.037 \\
\hline & $.6, .6$ & +.025 & -.048 & -.023 \\
\hline
\end{tabular}

${ }^{a}(-)$ denotes decrease $(+)$ denotes increase.

${ }^{b}$ Treatment effect of lactose level $(P<.01)$.

Treatment effect of Ca level $(P<.05)$.

$\mathrm{d}_{\text {Treatment effect of } P \text { level }(P<.01)}$.

${ }^{\mathrm{e}} \mathrm{Ca}$ level $\times \mathrm{P}$ level interaction $(\mathrm{P}<.01)$.

$f_{\text {Lactose }} \times \mathrm{Ca}_{\mathrm{a}} \times \mathrm{P}$ interaction $(\mathrm{P}<.05)$.

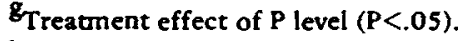

${ }^{h}$ Lactose $\times \mathrm{Ca} \times \mathrm{P}$ interaction $(\mathrm{P}<10)$.

${ }^{i} \mathrm{Ca} \times \mathrm{P}$ interaction $(\mathrm{P}<.05)$.

lactose. Levels of dietary $\mathrm{Ca}$ and $\mathrm{P}$ had no effect on stress to strain ratio.

No significant differences were observed for percentage of $\mathrm{Ca}, \mathrm{P}$ and ash in an average of three gut segments (from the duodenum, jejunum and ileum) across all treatments (table
10). When the mineral content of specific gut segments from all treatments was compared (tabel 11), percentage of $\mathrm{Ca}$ was found to be lower $(P<.10)$ and phosphorus and ash percentages greater $(\mathrm{P}<.01)$ in the ileum as compared to the average of duodenum and jejunum. When

TABLE 9. EFFECT OF LEVEL OF LACTOSE AND CA AND P LEVELS AND RATIOS ON BONE STRENGTH PARAMETERS OF GROWING-FINISHING SWINE

\begin{tabular}{|c|c|c|c|c|}
\hline \multirow[b]{2}{*}{$\begin{array}{l}\text { Dietary level of } \\
\text { lactose, } \%\end{array}$} & \multirow[b]{2}{*}{$\begin{array}{l}\text { Dietary level of } \\
\mathrm{Ca}_{\mathrm{a}} \text { and } \mathrm{P}, \%\end{array}$} & \multicolumn{3}{|c|}{ Bone strength parameters } \\
\hline & & $\begin{array}{l}\text { Peak force, } \\
\mathrm{kg}\end{array}$ & $\begin{array}{l}\text { Stress, } \\
\mathrm{kg} / \mathrm{cm}^{2}\end{array}$ & $\begin{array}{l}\text { Stress: strain } \\
\mathrm{kg} / \mathrm{cm}^{2} / \mathrm{mm}^{b}\end{array}$ \\
\hline \multirow[t]{4}{*}{0} & $.4, .4$ & 208 & 74.2 & 24.3 \\
\hline & $.4, .6$ & 204 & 74.2 & 25.7 \\
\hline & $.6, .4$ & 214 & 74.9 & 26.1 \\
\hline & $.6, .6$ & 218 & 77.3 & 26.4 \\
\hline \multirow[t]{4}{*}{30} & $.4, .4$ & 213 & 68.1 & 21.8 \\
\hline & $.4, .6$ & 194 & 71.6 & 24.4 \\
\hline & $.6, .4$ & 210 & 71.6 & 23.8 \\
\hline & $.6, .6$ & 216 & 76.2 & 26.7 \\
\hline
\end{tabular}

\footnotetext{
${ }^{a}$ Average of fresh femur and third and fourth metatarsal from one side.

${ }^{b}$ Treatment effect of lactose $(P<.05)$.
} 
TABLE 10. EFFECT OF LEVEL OF LACTOSE AND CA AND P LEVELS AND RATIOS ON MINERAL CONTENT OF GUT SEGMENTS ${ }^{a}$ AND ILEAL SEGMENTS ${ }^{b}$ ONLY OF GROWING-FINISHING SWINE

\begin{tabular}{|c|c|c|c|c|c|c|c|}
\hline \multirow{3}{*}{$\begin{array}{l}\text { Dietary level of } \\
\text { lactose, } \%\end{array}$} & \multirow{3}{*}{$\begin{array}{l}\text { Dietary level of } \\
\text { Ca and P, \% }\end{array}$} & \multicolumn{6}{|c|}{ Mineral content } \\
\hline & & \multicolumn{3}{|c|}{ Gut segments, \%ac } & \multicolumn{3}{|c|}{ Ileal segment, \%bc } \\
\hline & & $\mathrm{Ca}$ & $\mathbf{P}$ & Ash & $\mathrm{Ca}$ & $\mathbf{P}$ & Ash \\
\hline \multirow[t]{4}{*}{$\mathbf{0}$} & $.4, .4$ & .066 & .968 & 7.51 & .057 & 1.070 & 7.33 \\
\hline & $.4, .6$ & .068 & .967 & 7.82 & .054 & 1.055 & 7.93 \\
\hline & $.6, .4$ & .055 & .938 & 6.89 & .051 & .970 & 8.09 \\
\hline & $.6, .6$ & .057 & .930 & 7.24 & .054 & .975 & 7.67 \\
\hline \multirow[t]{4}{*}{30} & $.4, .4$ & .070 & 9.56 & 7.77 & .060 & .973 & 8.17 \\
\hline & $.4, .6$ & .056 & 1.007 & 7.17 & .052 & 1.104 & 7.96 \\
\hline & $.6, .4$ & .071 & .962 & 7.71 & .066 & 1.048 & 7.89 \\
\hline & $.6, .6$ & .074 & .995 & 6.92 & .046 & 1.111 & 8.05 \\
\hline
\end{tabular}

${ }^{\text {a }}$ Average of three 3 -cm segments; one each from duodenum, jejunum and ileum.

${ }^{\mathrm{b}}$ Segment taken $10 \mathrm{~cm}$ distal to cecum.

$\mathbf{c}_{\text {Percentage of dry weight. }}$

compared alone, the duodenum was found to have a lower $(\mathrm{P}<.01)$ percentage of phosphorus than the ileum.

\section{Discussion}

Postweaning rats and swine were able to tolerate lactose at levels up to $30 \%$ of the diet without suffering detrimental effects on growth rate, a finding similar to those of Riggs and Beaty (1947) for rats and Ekstrom et al. (1975b) for swine. The $29 \%$ reduction in gain noted during the first week among rats fed $30 \%$

TABLE 11. EFFECT OF LEVEL OF LACTOSE AND CA AND P LEVELS AND RATIOS ON MINERAL CONTENT OF SAMPLES FROM SPECIFIC GUT SEGMENTS OF GROWING-FINISHING SWINE

\begin{tabular}{lccc}
\hline & \multicolumn{3}{c}{ Gut segment $^{\mathrm{a}}$} \\
\cline { 2 - 4 } Item & Duodenum & Jejunum & Ileum \\
\hline $\mathrm{Ca}, \% \mathrm{~b}$ & .067 & .072 & .055 \\
$\mathrm{P}, \%$ cd & .931 & .935 & 1.038 \\
Ash, \%c & 7.81 & 6.34 & 7.84 \\
\hline
\end{tabular}

\footnotetext{
${ }^{a}$ Percentage of dry weight.

${ }^{b}$ Gut response duodenum, jejunum versus ileum (P<.01).

${ }^{c}$ Gut response duodenum, jejunum versus ileum $(\mathrm{P}<.10)$.

${ }^{\mathrm{d}}$ Gut response duodenum versus ileum $(\mathrm{P}<.01)$.
}

lactose was sufficiently compensated for in subsequent weeks so that no differences among treatments were observed in total gain. However, feed utilization in both rats and swine fed lactose was reduced compared to that in pigs and rats fed no lactose. Among swine, the poor feed conversion was attributed to a greater feed intake by pigs fed lactose. The transitory diarrhea and enlarged abdomens observed during the first week of the feeding period among rats fed $30 \%$ lactose were also observed by Riggs and Beaty (1947). In relation to these findings, Fischer (1957a) reported that an increase in size of the cecum, colon and rectum of rats fed $25 \%$ lactose was due to the large fraction of lactose that escaped hydrolysis and underwent fermentation in the intestine. After 1 week, incidence of diarrhea and other symptoms induced by the feeding of lactose decreased (Fischer, 1957b), suggesting that the rats had adapted to the $30 \%$ lactose diets. Adaptation may have resulted from dietary lactose causing an increase in lactase activity, as reported by Bolin et al. (1969). However, Leichter (1973) reported that intestinal lactase cannot be regulated by administration of dietary lactose. No symptoms of diarrhea were observed in pigs fed lactose, supporting the postulation of Atkinson et al. (1957) that pigs can tolerate lactose better than rats.

The lactose $\times$ Ca interaction observed in the pig trial suggests that pigs fed low $\mathrm{Ca}$ diets (.4\%) may benefit from the addition of lactose 
to the diet, as indicated by the increased serum Ca concentration.

The effect of lactose on alkaline phosphatase activity was similar in rats and swine. Alkaline phosphatase activity increased as lactose increased in the diets fed to rats, and it increased dramatically during the first 2 weeks in pigs fed lactose. This was in contrast to a gradual decrease in activity in pigs fed no lactose. This observation is similar to the findings of Liptrap et al. (1970). Because an increase in serum alkaline phosphatase activity is an indication of improper bone formation and because increased alkaline phosphatase activity would be expected only when dietary $\mathrm{Ca}$ levels were low (Hurwitz and Griminger, 1961; Miller et al., 1962), our results suggest that improper calcification was taking place. The rise in serum alkaline phosphatase was not compatible with the theory that lactose enhances $\mathrm{Ca}$ absorption in the gut. However, the increase in serum $\mathrm{Ca}$ that was observed when $.4 \% \mathrm{Ca}$ was fed to pigs in the presence of lactose supports the theory. The enhancing effect of lactose on serum alkaline phosphatase was not observed after 2 weeks, suggesting that the abnormal effects of lactose on Ca metabolism were corrected during the 2to 10 -week period. The effect of dietary $\mathrm{Ca}$ and $P$ on alkaline phosphatase activity was inconsistent.

The effect of lactose on bone-breaking strength was variable across all treatments. Since the change in alkaline phosphatase activity from 0 to 10 weeks in pigs fed lactose was no different from the change in activity in pigs fed no lactose (table 8), proper bone calcification may have been taking place for all pigs at the time of slaughter.

In the rat trial, percentage ash increased with increasing dietary lactose, a finding similar to that reported by Outhouse et al. (1937) and one which suggests a favorable effect of lactose on bone ash in rats. Alkaline phosphatase activities did not correspond with the bone ash results.

Mineral content of specific gut segments was analyzed to provide an indication of the effect of lactose on $\mathrm{Ca}$ and $\mathrm{P}$ absorption. Dietary treatment did not affect mineral content of the gut. Ca levels were low in all gut segments. The duodenum and ileum contained a higher percentage of ash than jejunum, suggesting that mineral absorption may be higher in these gut sections.

\section{Literature Cited}

Armbrecht, H. J. and R. H. Wasserman. 1976. Enhancement of $\mathrm{Ca}^{++}$uptake by lactose in the rat small intestine. J. Nutr. 106:1265.

Atkinson, R. L., F. H. Kratzer and G. F. Stewart. 1957. Lactose in animal and human feeding: $A$ review. J. Dairy Sci. 40:1114.

Barr, A. J. and J. H. Goodnight. 1972. A user's guide to the statistical analysis system (SAS). North Carolina State Univ., Raleigh.

Becker, D. E., S. W. Terrill, A. H. Jensen and L. J. Hanson. 1957. High levels of dried whey powder in the diet of swine. J. Anim. Sci. 16:404.

Bolin, T. D., R. C. Pirola and A. E. Davis. 1969. Adaptation of intestinal lactose in the rat. Gastroenterology 57:406.

Ekstrom, K. E., N. J. Benevenga and R. H. Grummer. 1975a. Changes in the intestinal lactase activity in the small intestine of two breeds of swine from birth to 6 weeks of age. J. Nutr. 105:1032.

Ekstrom, K. E., N. J. Benevenga and R. H. Grummer. 1975b. Effects of various dietary levels of dried whey on the performance of growing pigs. J. Nutr. $105: 846$.

Entringer, R. P., M. P. Plumlee, J. H. Conrad, T. R. Cline and $S$. Wolfe. 1975. Influence of diet on passage rate and apparent digestibility by growing swine. J. Anim. Sci. 40:486.

Fischer, J. E. 1957a. Effects of feeding a diet containing lactose upon D-galactosidase activity and organ development in the rat digestive tract. Amer. J. Physiol. 188:49.

Fischer, J. E. 1957b. Effects of feeding diets containing lactose, agar, cellulose, raw potatoe starch, or arabinose on the dry weights of cleaned gastrointestional tract organs in the rat. Amer. J. Physiol. 188:550.

Goldenberg, H. and A. Fernandez. 1966. Simplified method for the estimation of inorganic phosphorus in body fluids. Clin. Chem. 12:871.

Harvey, W. R. 1960. Least-squares analysis of data with unequal subclass numbers. USDA, ARS 20-8.

Hurwitz, S. and P. Griminger. 1961. The response of plasma alkaline phosphatase, parathyroids and blood and bone minerals to calcium intake in the fowl. J. Nutr. 73:177.

Kline, O. L., J. A. Keenan, C. A. Elvehjem and E. B. Hart. 1932. Lactose in nutrition. J. Biol. Chem. 98:121.

Kobayashi, A., S. Kawai, Y. Ohbe and Y. Nagashima. 1975. Effects of dietary lactose and a lactase preparation on the intestinal absorption of calcium and magnesium in normal infants. Amer. J. Clin. Nutr. 28:681.

Leichter, J. 1973. Effect of dietary lactose on intestinal lactase activity in young rats. J. Nutr. 103:392.

Lengemann, F. W., R. H. Wasserman and C. L. Comar. 1959. Studies on the enhancement of radiocalcium and radiostrontium absorption by lactose in the rat. J. Nutr. 68:443.

Liptrap, D. O., E. R. Miller, D. E. Ullrey, K. K. Keahey and J. A. Hoefer. 1970. Calcium levels for developing boars and gilts. J. Anim. Sci. 31:540.

Miller, E. R., D. E. Ullrey, C. L. Zutant, B. V. Baltzer, D. A. Schmidt, J. A. Hoefer and R. W. Luecke, 
1962. Calcium requirement of the baby pig. $J$. Nutr. 77:7.

Outhouse, J., J. Smith, L. Merritt and F. R. White. 1937. A comparative study of the growth promoting and bone calcifying effects of several carbohydrates. J. Nutr. 14:579.

Riggs, L. K. and A. Beaty. 1947. Some unique properties of lactose as a dietary carbohydrate. J. Dairy Sci. 30:939.

Robinson, C. S., C. F. Huffman and M. F. Mason. 1929. The results of the ingestion of certain calcium salts and of lactose. J. Biol. Chem. 84:257.
Sewell, R. F. and J. P. West. 1965. Some effects of lactose on protein utilization in the baby pig. J. Anim. Sci. 24:239.

Sigma Chemical Co. 1974. The colorimetric determination of phosphatase. Tech. Bull. No. 104 (Revised Ed.), St. Louis, MO.

Simoons, F. J. 1969. Primary adult lactose intolerance and the milking habit: A problem in biological and cultural interrelations. 1 . Review of medical research. Amer. J. Dig. Dis. 14:819.

Steel, R.D.G. and J. H. Torrie. 1960. Principles and Procedures of Statistics. McGraw-Hill Book Co., Inc., New York. 